\title{
THE EFFECT OF PLASMA PREPARATION RICH IN GROWTH FACTORS ON PATELLAR STABILITY AFTER MEDIAL PATELLOFEMORAL LIGAMENT REEFING
}

\author{
Andonovski Alan, ${ }^{1}$ Nancheva Jasminka, ${ }^{1}$ Andonovska Biljana, ${ }^{1}$ \\ Petrovska-Cvetkovska Dragana, ${ }^{2}$ Nanceva Andrea, ${ }^{3}$ Alabakovska Sonja ${ }^{4}$ \\ ${ }^{1}$ University Clinic for Orthopedic Surgery, Traumatology, Anesthesiology and Intensive Care, \\ Clinical center Skopje, Skopje, R. Macedonia \\ ${ }^{2}$ University Clinic for Neurology,Clinical center Skopje, Skopje, R. Macedonia \\ ${ }^{3}$ General Hospital "8th of September", Skopje, R. Macedonia \\ ${ }^{4}$ Institute of Medical and Experimental Biochemistry, Faculty of Medicine, \\ University "Ss Cyril and Methodius" Skopje, R. Macedonia
}

Primljen/Received 06. 05. 2016. god.

Abstract: Introduction: Although more than 100 operative procedures have been described for the treatment of patellar instability, there is no single universally successful procedure. For the most patients with lateral patellar instability medial patellofemoral ligament (MPFL) reefing is recommended. When we perform MPFL reefing we are not aware of the quality and strength of the MPFL tissue. In the presence of recurrent patellar instability, the quality and strength of MPFL tissue is often compromised and it disturbs patellar stability after MPFL reefing. Biomedicine development, recognizing the ligament healing process show us that autologous blood products, particularly PRP can enhance healing in soft tissue injuries.

Purpose: The purpose of this study was to determine the potential effect of Plasma preparation rich in growth factors on patellar stability after MPFL reefing.

Material and methods: Plasma preparation rich in growth factors was produced from a unit of autologous whole blood using Arthrex ACP double syringe system.Platelet gel was prepared by adding bovine thrombin and $10 \%$ solution of calcium chloride. The platelet gel was applied locally into the place where suturing of the MPFL was performed. In this prospective, randomized and double blind study 12 patients were included:6 patients in the PG group who received platelet gel and 6 patients in the control group who were not treated with platelet gel. Patellar stability was evaluated before surgery and 3 months after surgery with Axial stress radiographs.
Prihvaćen/Accepted 17. 06. 2016. god.

Results: The calculated 3 month improvement was $12.67 \pm 2.51$ in the control group and $17.33 \pm 1.52$ in the PG group, $(p=0.064)$. Although there was greater improvement in patellar stability in PG group comparing to the control group, the difference was not statistically significant $(p>0.05)$. The main reason for this was probably the small number of patients included in the study.

Conclusion: Results showed that growth factors from the plasma preparation rich in growth factors have positive effect on patellar stability after MPFL reefing. We believe that they stimulate and accelerate physiological healing and reparative tissue processes in ligament healing. More studies should be made, including more patients, if we want to get more relevant results.

Keywords: patellar instability, medial patellofemoral ligament reefing, plasma preparation rich in growth factors, clinical results.

\section{INTRODUCTION}

Patellar instability is a complex problem for orthopedic surgery especially when a specific operative treatment should be chosen. Although more than 100 operative procedures have been described for the treatment of patellar instability, there is no single universally successful procedure. The multifactorial etiology is probably the main reason for those treatment dilemmas. For the patients with patellar instability who have normal tibial tubercle-trochlear groove (TT-TG) dis- 
tance, normal patellar height and no marked trochlear dysplasia, medial patellofemoral ligament (MPFL) reefing or reconstruction is recommended. In patients who have increased TT-TG distance or patella alta, distal realignment procedures are used. Trochleoplasty is rarely indicated in patients with marked trochlear dysplasia. Because studies have shown that MPFL is the most significant passive stabilizer of the patella (1), and because they have shown that MPFL heals and is elongated in majority of patellar dislocation cases (2), most of the authors recommend reefing or reconstruction of MPFL for the treatment of patellar instability. With MPFL reefing similar to capsulorrhaphy for treating shoulder instability, plication of the redundant tissue of the elongated MPFL is done. The procedure is performed by suturing with PDS sutures under arthroscopic control. The result of this procedure is MPFL tightening and obtaining a normal position and normal tracking of the patella.

When we perform MPFL reefing we are not aware of the quality and strength of MPFL tissue. The MPFL has approximately $12 \mathrm{~N}$ of strength and a load to failure of approximately $208 \mathrm{~N}$. In the presence of recurrent traumatic lateral patellar instability, this relatively frail structure has been torn many times over, not only in its mid substance, but often at its attachment points (3). So, sometimes there is a question if to repair the tissue that has already failed many times over.

Recently, advances in biomedicine and biotechnology have shown the use of cell therapy, tissue engineering, and autologous blood concentrates to enhance healing in bone and soft tissue injuries (4). One of these methods used to biologically augment healing in the fields of orthopaedic surgery and sports medicine includes the use of autologous blood products, particularly, platelet rich plasma (PRP). Platelet rich plasma (PRP) is a portion of plasma fraction from autologous blood with platelet concentration above baseline (5). It is produced from a patient's peripheral vein and centrifuged to achieve a high concentration of platelets within a small volume of plasma. There are numerous protocols and commercial systems for producing PRP. Traditionally, two centrifugation steps are used to isolate the erythrocyte fraction from the buffy coat (plasma containing platelets, leukocytes, and clotting factors). The second step separates the platelet-poor plasma from the platelet-rich fraction. Single-step systems are also available. Once activated, platelets begin to secrete many growth factors, chemokines, cytokines, and inflammatory mediators. Platelets begin to secrete these growth factors within 10 minutes after clothing, $95 \%$ of growth factors are secreted within 1 hour and they continue to secrete during their life (5 to 10 days) (6). They have an influence on many aspects of ligament healing (7) (Table 1).

During PRP production it is important to keep the platelet activation on minimum, because secreted proteins will be released earlier and they might be lost and not transferred to the right surgical place. During centrifugation platelet activation and fragmentation can be avoided by use of acid citrate dextrose anticoagulant and low gravity forces (8). Platelet activation and platelet gel production can be achieved by adding calcium chloride and thrombin to PRP (9). The thrombin directly activates platelets and calcium ion replenishes the calcium that was previously bound with anticoagulant citrate dextrose.

There are a lot of studies that describe the clinical use of PRP in orthopedic practice. Some of them describe the effect of PRP on medial collateral ligament healing (10), other the effect of PRP on graft healing after ACL reconstruction (11), or donor site morbidity after ACL reconstruction with BTB graft (12). Many studies show the use of PRP in patient with cartilage damage (13), plantar

Table 1. Synopsis of growth factors present in PRP by Peter AM Everts (7)

\begin{tabular}{|l|l|}
\hline \multicolumn{1}{|c|}{$\begin{array}{c}\text { Platelet growth } \\
\text { factor }\end{array}$} & \multicolumn{1}{c|}{ Function } \\
\hline $\begin{array}{l}\text { Transforming growth } \\
\text { factor } \beta \text { (TGF- } \beta \text { ) }\end{array}$ & $\begin{array}{l}\text { Stimulates mesenchymal cell proliferation; regulates endothelial, fibroblastic, and oste- } \\
\text { oblastic mitogenesis; regulates collagen synthesis and collagenase secretion;stimula- } \\
\text { tes endothelial chemotaxis and angiogenesis }\end{array}$ \\
\hline $\begin{array}{l}\text { Platelet-derived } \\
\text { growth factor (PDGF) }\end{array}$ & $\begin{array}{l}\text { Mitogenetic for mesenchymal cells and osteoblasts; stimulates chemotaxisand mito- } \\
\text { genesis in fibroblast; regulates collagenase secretion and collagen synthesis; stimula- } \\
\text { tes macrophageand neutrophile chemotaxis }\end{array}$ \\
\hline $\begin{array}{l}\text { Basic fibroblast } \\
\text { growth factor, BFGF }\end{array}$ & $\begin{array}{l}\text { Promotes growth and differentiation of chondrocytes andosteoblasts; mitogenetic for } \\
\text { mesenchymal cells, chondrocytes and osteoblasts }\end{array}$ \\
\hline $\begin{array}{l}\text { Epidermal growth } \\
\text { factor, EGF }\end{array}$ & $\begin{array}{l}\text { Stimulates endothelial chemotaxis/angiogenesis; regulates collagena sesecretion; sti- } \\
\text { mulates epithelial/mesenchymal mitogenesis }\end{array}$ \\
\hline $\begin{array}{l}\text { Vascular endothelial } \\
\text { growth factor, VEGF }\end{array}$ & $\begin{array}{l}\text { Increases angiogenesis and vessel permeability, stimulates mitogenesis for endothe- } \\
\text { lial cells }\end{array}$ \\
\hline $\begin{array}{l}\text { Connective tissue } \\
\text { growth factor, CTGF }\end{array}$ & Promotes angiogenesis, cartilage regeneration, fibrosis and platelet adhesion \\
\hline
\end{tabular}


fasciitis (14), epicondylitis (15, 16, 17), jumpers' knee $(18,19)$. In current data bases we have not found studies that describe the effect of PRP on MPFL healing after its reefing in patients with patellar instability.

Our study was designed to determine the potential effect of locally applied plasma preparation rich in growth factors on patellar stability after MPFL reefing.

\section{PATIENTS, MATERIALS AND METHODS}

\section{Patient selection}

Twelve patients between 12 and 33 years of age were included in our study. They were operated on, in the period from March 2013 to March 2014 in the University Clinic for Orthopedic Surgery in Skopje, Macedonia. Patellar instability in all of them was diagnosed preoperatively with accurate history, physical examination and imaging studies. Patients with inflammatory diseases, malignant diseases, diabetes mellitus, renal diseases, thrombocytopenia, immunological diseases, knee osteoarthritis and previous knee surgery were excluded from the study. Patients with patellar instability who had marked trochlear dysplasia, patella alta or TT-TG distance more than 20 mm were also excluded from the study because MPFL reefing is not a suitable operative procedure for treating these patients. Patients were divided into two groups: PG group and the control group. The PG group had 6 patients in whom plasma prepared platelet gel was locally applied during the operative procedure (MPFL reefing). The control group had 6 patients and they did not receive platelet gel during the same operative procedure. Randomization was performed with closed envelopes, with number 1 for PG group and number 2 for control group. In all patients the same operative procedure (MPFL reefing) was performed. All patients were operated by the same surgeon (A. A.), and in all of them the same rehabilitation protocol was performed by the same physiotherapist. RTG evaluation was made by an independent radiologist in a blinded fashion. The study was prospective, randomized and double blind.

\section{Surgical technique}

The operative procedure started with routine arthroscopy, where inspection of the knee and assessment of patellar position and patellar tracking was made. In patients with marked lateralization of the patella MPFL reefing was performed. Skin incision $1-1.5 \mathrm{~cm}$ long was made near the medial patellar border. We use two needles: needle with free end suture and needle with suture loop (PDS 1 suture). We inserted the free end suture needle through the periosteum of the medial patellar facet. The needle with suture loop was inserted $2-5 \mathrm{~cm}$ medially depending on the amount of reefing
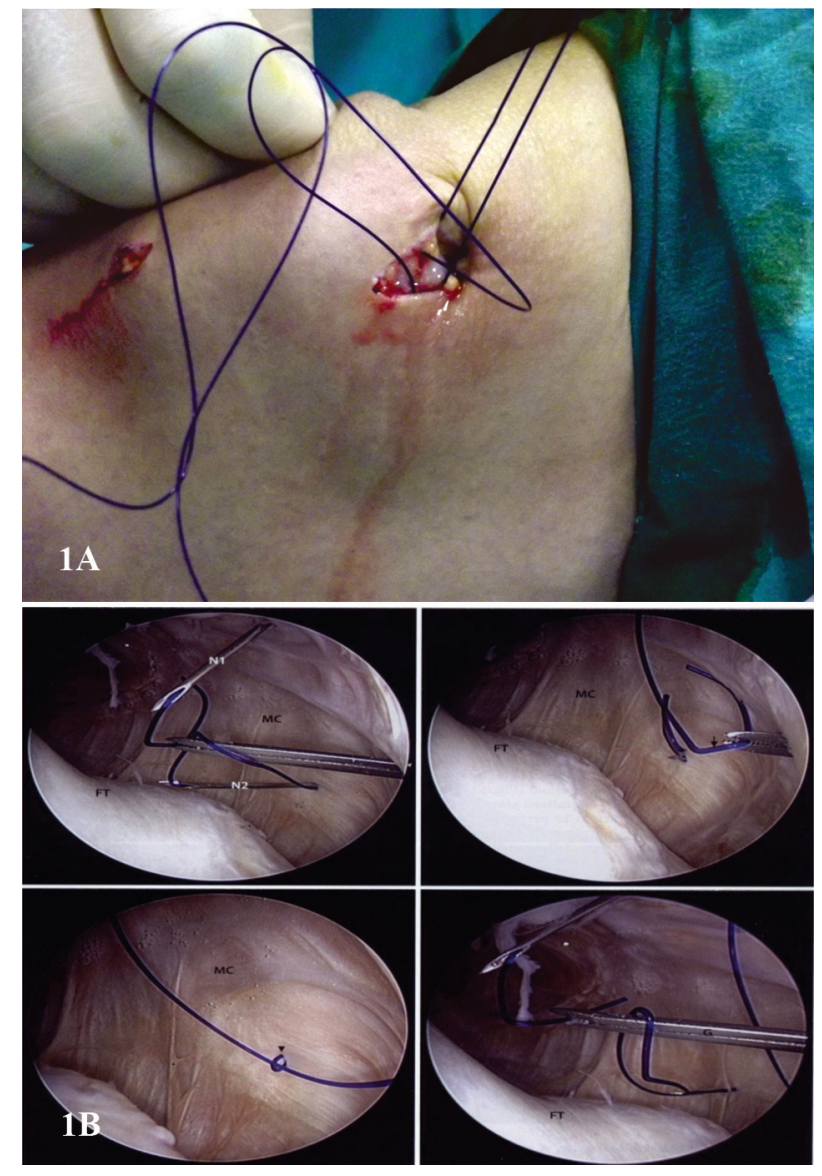

Figure 1. MPFL reefing operative technique. A: View outside knee joint; B: Arthroscopic view inside knee joint

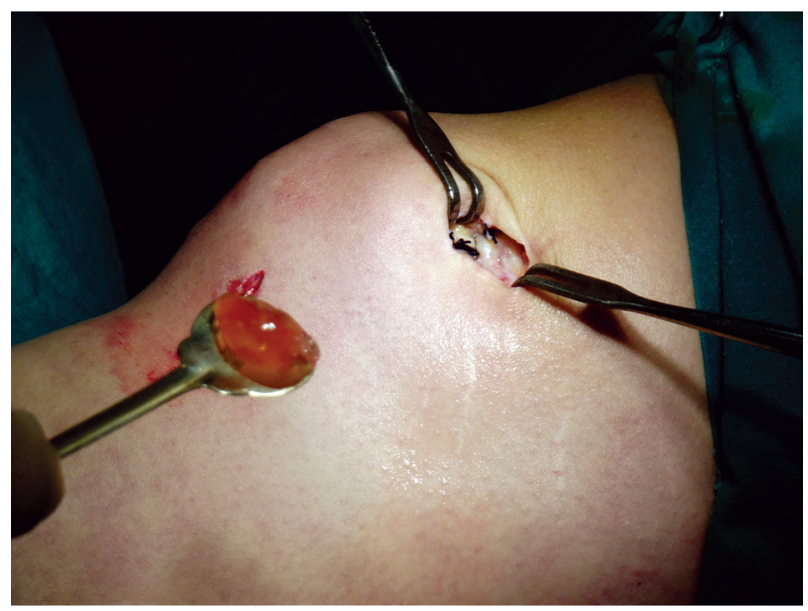

Figure 2. Medial patellar incision where the platelet gel is applied

desired. The free end suture was then pulled outside the knee joint with the needle with suture loop. Three to five sutures were placed in this way. Patellar position was checked while tension was placed on the sutures, and if the position was correct, the sutures were tied with the knee in extension (Figure 1). In patients from the PG group, platelet gel was applied in the place where the sutures were tied (Figure 2). 


\section{Platelet gel preparation}

Platelet rich plasma was produced using Arthrex double syringe system. For that purpose $15 \mathrm{ml}$ of patient's whole blood was drawn and centrifuged on 1500 prp for 5 minutes. When centrifugation was finished three layers were formed: the bottom layer consisting of red blood cells, the middle layer consisting of platelets and white blood cells, and the top plasma layer. With the other smaller syringe about $3 \mathrm{ml}$ plasma with platelets and white blood cells was then drawn from the bigger syringe. Platelets activation and platelet gel formation was performed by adding a solution of 1000 units of topical bovine thrombin and $1 \mathrm{ml}$ of $10 \%$ calcium chloride to the PRP. Because we got $3 \mathrm{ml} \mathrm{PRP,} \mathrm{ac-}$ cording to the Marx et al. study (5), $0.5 \mathrm{ml}$ of calcium chloride/thrombin solution were mixed with $3 \mathrm{ml}$ PRP and platelet gel was prepared.

\section{Rehabilitation}

All the patients had the same rehabilitation protocol. Brace was used postoperatively for 6 weeks. Flexion of 30 degrees was allowed after the first 2 weeks postoperatively, 60 degrees flexion in the 3-rd week and 90 degrees flexion in the 4-th postoperative week. All the patients used crutches for 4 weeks and full weight bearing was allowed in the 4th postoperative week. Physiotherapy was performed after 6 weeks by the same physiotherapist.

\section{Follow up evaluation}

Postoperatively, after 3 months, all patients underwent a physical examination and Axial radiograph was performed to determine the patellar displacement.Axial view was then repeated while a medial force was applied to the patella, so stress radiographs of the patellofemoral joint were made (Figure 3). The applied force was kept constant with the use of a special force gange model FG-5005 instrument and the patellar displacement was measured with the technique described by Laurin et al. (20). Statistically mean value, standard deviation and standard error were calculated, and using

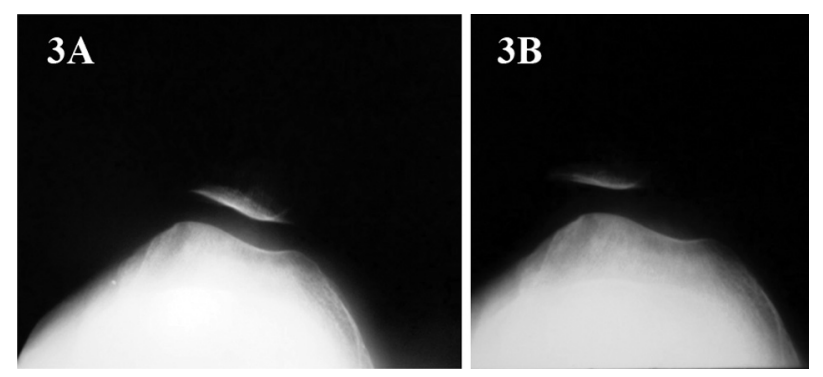

Figure 3. A: Axial knee radiograph; B: Axial stress radiograph the t-test a statistically significant difference between PG group and control group was determined.

\section{RESULTS}

Axial radiographs and stress radiographs were made preoperatively and 3 months postoperatively. The difference in patellar stability between PG group and control group measured with the technique described by Laurin et al. was calculated (Table 2).

Table 2. Difference in patellar stability between $P G$ group and control group (mm)

\begin{tabular}{|l|c|c|c|c|}
\hline & N & Mean & $\begin{array}{c}\text { Std. } \\
\text { Deviation }\end{array}$ & $\begin{array}{c}\text { Std. Error } \\
\text { Mean }\end{array}$ \\
\hline Control group & 6 & 12.67 & 2.517 & 1.453 \\
\hline PG group & 6 & 17.33 & 1.528 & 0.882 \\
\hline
\end{tabular}

The calculated 3 month improvement was $12.67 \pm$ 2.51 in the control group and $17.33 \pm 1.52$ in the PG group, $(p=0.064)$. Although there was greater improvement in patellar stability in PG group comparing to the control group, the difference was not statistically significant $(\mathrm{p}>0.05)$. The main reason for this is probably the small number of patients included in the study.

\section{DISCUSSION}

Patellar instability is the least known (the black hole in orthopedics) and the most problematic and controversial pathology of the knee. Although there are some dilemmas according to the etiology and diagnosis of the patellar instability, the biggest dilemma arises when the right operative treatment should be chosen. There are some surgeons, for example, Prof. Jeffrey Halbrecht's, who propose that MPFL reefing is the best procedure for treating patellar instability (21). According to them, MPFL reefing is indicated for the most cases of patellar instability. "It gives good clinical and radiographic stability, complications are rare, it is easy to perform, and does not cost much", writes Prof. Halbrecht. Surgeons who perform MPFL reefing have a problem because they do not know the strength and quality of the MPFL and that has large influence on MPFL healing and postoperative patellar stability when reefing of the MPFL is done. "Does it make sense to repair tissue that has failed many times before?" writes prof. Schepsis (3).

Advances in biomedicine and biotechnology show us that autologous blood products, particularly PRP, can enhance healing in soft tissue injuries biologically. Its use in the treatment of musculoskeletal injuries is described in many studies.Recognizing the ligament healing process, we become aware of the impor- 
tance of platelet growth factors during this process (22). Growth factor responses at the initial inflammatory and proliferative phases of ligament healing are critical for the filling of tissue defect with neo fibrous tissue (23). That was the reason why we have decided to determine the effect of plasma preparation rich in growth factors in improving the healing process of previously damaged tissue of MPFL and in improving the patellar stability after MPFL reefing in our study.

Arthrex double syringe system was used for producing PRP. It gives up to 3-fold increase in platelet concentration over baseline. Some investigators suggest that PRP should achieve a 3 to 5 -fold increase in platelet concentration over baseline (24), although the dependence of clinical benefit on platelet concentration versus total number of platelets delivered may need further investigations (25). According to Weibrich et al. (26), different individuals need different platelet concentrations to get right biological effect. We prepared platelet gel because we needed prolonged secretion of growth factors during whole platelets life on the right surgical site.

Because stress radiographs provide the only available objective measurement of patellofemoral joint instability, we have decided to use them for preoperative and postoperative evaluation of the patellar stability (27). Because patellar instability most often occurs in the first 30 degrees of knee flexion we made Axial view with 30 degrees of knee flexion with and without medial force applied to the patella to get stress radio- graphs. All the patients had lateral instability and that is why only the lateral displacement was measured. It was important to keep the applied force constant with special instrument and to make right measurement according to Laurin et al. (20).

\section{CONCLUSION}

Although there was not statistical significance $(\mathrm{p}=$ 0.064), the results showed that the patients from the PG group have improved their patellar stability more than the patients from the control group. That means that growth factors from the platelet gel have positive effect on patellar stability after MPFL reefing. We believe that they stimulate and accelerate physiological healing and reparative tissue processes in ligament healing.

More studies should be made, including more patients, if we want to get more relevant statistically significant results.

\section{Conflict of interest}

The authors declare no conflict of interest.

Abbreviations

MPFL - Medial Patellofemoral Ligament

TT-TG distance - Tibial Tubercle-Trochlear Groove distance

PRP — Platelet Rich Plasma

\title{
Sažetak
}

\section{UTICAJ PLAZMA PREPARATA BOGATOG FAKTORIMA RASTA NA PATELARNU STABILNOST NAKON ŠIVENJA MEDIJALNOG PATELOFEMORALNOG LIGAMENTA}

\author{
Andonovski Alan, ${ }^{1}$ Nancheva Jasminka, ${ }^{1}$ Andonovska Biljana, \\ Petrovska-Cvetkovska Dragana, ${ }^{2}$ Nanceva Andrea, ${ }^{3}$ Alabakovska Sonja ${ }^{4}$ \\ ${ }^{1}$ University Clinic for Orthopedic Surgery, Traumatology, Anesthesiology and Intensive Care, \\ Clinical center Skopje, Skopje, R. Macedonia \\ ${ }^{2}$ University Clinic for Neurology, Clinical center Skopje, Skopje, R. Macedonia \\ ${ }^{3}$ General Hospital "8th of September", Skopje, R. Macedonia \\ ${ }^{4}$ Institute of Medical and Experimental Biochemistry, Faculty of Medicine, \\ University "Ss Cyril and Methodius" Skopje, Macedonia
}

Uvod: I pored toga što je opisano više od 100 operativnih procedura u tretmanu patelarne nestabilnosti, danas, još uvek, ne postoji jedinstvena uspešna univerzalna procedura. Za većinu pacijenata sa patelarnom nestabilnošću preporučuje se šivenje medijalnog patelofemoralnog ligamenata (MPFL - Medial patellofemoral ligament). Prilikom šivenja medijalnog patelofemoralnog ligamenta mi nemamo saznanje u kvalitet i čvrstoću njegovog ligamentarnog tkiva. Kod rekurentne patelarne nestabilnosti kvalitet i čvrstoća ligamentarnog tkiva su često kompromitovane i to narušava patelarnu stabilnost nakon šivenja medijalnog patelofemoralnog ligamenta. Razvitak biomedicine, poznavajući process ligamentarnog zarašćivanja, pokazuje da autologni produkt krvi, u velikoj meri plazme koja je bogata trombocitima, može stimulisati zarašćivanje mekotkivnih povreda. 
Cilj: Cilj ove studije je da utvrdi potencijalni uticaj plazma preparata bogatog faktorima rasta na patelarnu stabilnost nakon šivenja medijalnog patelofemoralnog ligamenta.

Materijal i metode: Plazma preparat koji je bogat faktorima rasta, dobijamo od autologne krvi pacijenata koristeći Arthrex ACP double syringe system. Dodajući boving (govedi) trombin i 10\% rastvor calcium hlorida dobjamo trombocitni gel kojeg lokalno apliciramo na mesto gde je urađeno šivenje medijalnog patelofemoralnog ligamenta. U ovoj prospektivnoj, randomiziranoj i dvostruko slepoj studiji bilo je uključeno 12 pacijenata: 6 u takozvanoj PG grupi koji su dobili trombocitni gel i $6 \mathrm{u}$ kontrolnoj grupi koji nisu bili tretirani gelom. Patelarna stabilnost bila je evaluirana pre operacije i 3 meseca posle operacije sa aksijalnim stress radiografijama.

Rezultati: Preračunato, tromesečno poboljšanje bilo je $12.67 \pm 2.51 \mathrm{~mm}$ u kontrolnoj i $17.33 \pm$

\section{REFERENCES}

1. Hautamaa PV, Fithian DC, Kaufman KR, Daniel DM, Pohlmeyer AM. Medial soft tissue restraints in lateral patellar instability and repair. Clin Orthop Relat Res. 1998; 349: 174-82.

2. Tom A, Fulkerson P. Restoration of native medial patellofemoral ligament support after patella dislocation. Sports Med. Arthroscopy. 2007; 15(2): 68-71.

3. Schepsis A, Rogers AJ. Medial patellofemoral ligament reconstruction: indications and technique. Sports Med Arthrosc. 2012; 20(3): 162-70.

4. Middleton KK, Barro V, Muller B, Terada S, Fu FH. Evaluation of the effects of platelet-rich plasma (PRP) Therapy involved in the healing of sports-related soft tissue injuries. Iowa Orthop J. 2012; 32: 150-63.

5. Marx RE. Platelet-rich plasma (PRP): What is PRP and whatis not PRP? Implant Dent. 2001; 10(4): 225-8.

6. Marx RE. Platelet-rich plasma: Evidence to support its use.J. Oral Maxillofac. Surg. 2004; 62(4): 489-96.

7. Everts AP, Knape JT, Weibrich G, et al. Platelet-Rich Plasma and Platelet Gel: A Review. J Extra Corpor Technol. 2006; 38(2): 174-87.

8. Gonshor A. Technique for producing platelet-rich plasma and platelet concentrate: Background and process. Int. J. Periodontics Restorative Dent. 2002; 22(6): 547-57.

9. Petrungaro PS. Using platelet-rich plasma to accelerate soft tissue maturation in esthetic periodontal surgery. Compend. Contin. Educ. Dent. 2001; 22(9): 729-32.

10. Yoshioka T, Kanamori A, Washio T, et all. The effects of plasma rich in growth factors (PRGF-Endoret) on healing of medial collateral ligament of the knee. Knee Surg Sports Traumatol Arthrosc. 2013; 21(8): 1763-9.

11. Andriolo L. Di Matteo B, Kon E, Filardo G, Venieri G, Marcacci M. PRP Augmentation for ACL Reconstruction. Bio Med Res Int. 2015;2015:371746. doi: 10.1155/2015/371746.

12. Cervellin M. de Girolamo L, Bait C, Denti M, Volpi P. Autologous platelet-rich plasma gel to reduce donor-site morbidity after patellar tendon graft harvesting for anterior cruciate li-
$1.52 \mathrm{~mm}$ u PG grupi. I pored toga što smo dobili veće poboljšanje u patelarnoj stabilnosti u PG grupi u odnosu na kontrolnu grupu, ipak ta razlika nije bila statistički signifikantna ( $\mathrm{p}>0,05)$. Glavni razlog za to bio je najverovatnije mali broj pacienata uključenih u studiju.

Zaključak: Dobijeni rezultati pokazuju da faktori rasta dobijeni iz plazma preparata bogatog faktorima rasta, imaju pozitivni uticaj na patelarnu stabilnost nakon šivenja medijalnog patelofemoralnog ligamenta. Mi verujemo da oni stimulišu ubrzavanje fiziološkog zarašćivanja i reparativne tkivne procese kod ligamentarnog zarašćivanja. Potreban je veci broj studija sa većim brojem pacijenata kako bi dobili relevantnije rezultate.

Ključne reči: patelarna nestabilnost, šivenje medijalnog patelofemoralnog ligamenta, plazma preparat bogat faktorima rasta, klinicki rezultati.

gament reconstruction: a randomized, controlled clinical study. Knee Surg. Sports Traumatol. Arthrosc. 2012; 20(1): 114-20.

13. Gobbi A, Karnatzikos G, Mahajan V, Malchira S. Platelet-rich plasma treatment in symptomatic patients with knee osteoarthritis: preliminary results in a group of active patients. Sports Health. 2012; 4(2): 162-72.

14. Lopez-Gavito E. Gomez-Carlín LA, Parra-Tellez P, Vazquez-Escamilla J. Platelet-rich plasma for managing calcaneus tendon tendinopathy and plantar fasciitis. Acta Orthop Mex. 2011; 25(6): 380-5.

15. Chaudhury S, de La Lama M, Adler RS, et all. Platelet-rich plasma for the treatment of lateral epicondylitis: sonographic assessment of tendon morphology and vascularity (pilot study). Skeletal Radiol. 2013; 42(1): 91-7.

16. Gosens T, Peerbooms JC, van Laar W, den Oudsten BL. Ongoing positive effect of platelet-rich plasma versus corticosteroid injection in lateral epicondylitis: A double-blind randomized controlled trial with 2-year follow-up. Am J Sports Med. 2011; 39(6): 1200-8

17. Hechtman KS, Uribe JW, Botto-van Demden A, Kiebzak GM. Platelet-rich plasma injection reduces pain in patients with recalcitrant epicondylitis. Orthopedics. 2011; 34(2):92.

18. Filardo G, Kon E, Della Villa S, Vincentelli F, Fornasari PM, Marcacci M. Use of platelet-rich plasma for the treatment of refractory jumper's knee. IntOrthop. 2010; 34(6): 909-15.

19. Kon E, Filardo G, Delcogliano M, et al. Platelet-rich plasma: New clinical application: A pilot study for treatment of jumper's knee. Injury. 2009; 40(6): 598-603.

20. Laurin CA, Dussault R, Levesqu HP. The tangential $\mathrm{x}$-ray investigation of patellofemoral joint: $\mathrm{x}$-ray technique, diagnostic criteria, and their interpretation. Clin Orthop Relat Res. 1979; 144: 16-26.

21. Halbrecht JL. Arthroscopic patella realignment: An all-inside technique. Arthroscopy. 2001; 17(9): 940-5.

22. Anderson, JM. The cellular cascades of wound healing. In: Davies JE, Editor. Bone Engineering. Toronto: em squared inc., 2000: p.81-93.

23. Buckwalter JA, Einhorn TA, Bolander ME. Healing of musculoskeletal tissues. In: Rockwood CA, Bucholz RW Jr, 
Green DP, Eds., Fractures in Adults. Philadelphia: Lippincott Raven, 1996: p. 261-304.

24. Kevy SV, Jacobson MS. Comparison of methods forpoint of care preparation of autologous platelet gel. J. Extra Corpor. Technol. 2004; 36(1): 28-35.

25. Waters JH, Roberts KC. Database review of possiblefactors influencing point-of-care platelet gel manufacture. J Extra Corpor Technol. 2004; 36(3): 250-4.

\section{Correspondence to / Autorzakorespondenciju}

Alan Andonovski, MD.

University Clinic for Orthopedic Surgery,

Faculty of Medicine, University "Ss. Cyril and Methodius",

Skopje, Republic of Macedonia

Tel.: +38970261624

E-mail: alanandonovski@t-home.mk
26. Wibrich G, Kleis WK, Hafner G, Hitzler WE Growth factor levels in platelet-rich plasma and correlations with donor age, sex, and platelet count. J Craniomaxillofac Surg. 002; 0(2): 97-02.

27. Dzoleva-Tolevska R, Poposka A, Georgieva D, Bozinovski Z, Nanceva J, Gjoshev S. Comparative analyses of diagnostic methods in knee injuries. Sanamed. 2016; 11(1): $39-45$. 